\title{
PENGARUH RELIGIUSITAS TERHADAP KEPATUHAN WAJIB PAJAK DENGAN KESADARAN WAJIB PAJAK SEBAGAI VARIABEL INTERVENING
}

(STUDI KASUS PADA WAJIB PAJAK ORANG PRIBADI YANG TERDAFTAR PADA KANTOR PELAYANAN PAJAK (KPP)

PRATAMA KUDUS)

\begin{abstract}
Tema yang diangkat dari penelitian ini adalah tentang kepatuhan wajib pajak yang ada di Kantor Pelayanan Pajak Kudus, dengan judul "Pengaruh Religiusitas Terhadap Kepatuhan Wajib Pajak dengan Kesadaran Wajib Pajak Sebagai Variabel Intervening (Studi Kasus pada Wajib Pajak Orang Pribadi pada Kantor Pelayanan Pajak (KPP) Pratama Kudus)". Penelitian ini merupakan studi kasus pada wajib pajak orang pribadi di Kabupaten Kudus. Populasi dari penelitian ini adalah seluruh wajib pajak orang pribadi di Kabupaten Kudus. Sampel diambil secara insidental sampling. Pengujian hipotesis dilakukan dengan menggunakan pendekatan Structural Equation Model (SEM) dengan menggunakan metode alternatif Warp Partial Least Square (PLS). Hasil penelitian menunjukkan bahwa : 1). Religiusitas berpengaruh terhadap kepatuhan wajib pajak, 2). Religiusitas berpengaruh terhadap kesadaran wajib pajak, 3). Kesadaran wajib pajak berpengaruh terhadap kepatuhan wajib pajak, 4). Kesadaran wajib pajak mampu memediasi sebagian pengaruh religiusitas terhadap kepatuhan wajib pajak.
\end{abstract}

Kata kunci: religiusitas, kesadaran wajib pajak, kepatuhan wajib pajak, wajib pajak orang pribadi

\section{PENDAHULUAN}

Pajak merupakan sumber Anggaran Pendapatan Dan Belanja Negara (APBN) yang digunakan untuk memenuhi kebutuhan Negara. Peran yang dimiliki oleh pajak sangat penting demi mendukung kelancaran perekonomian di Negara Indonesia. Oleh karena itu penerimaan pajak di Indonesia mendapatkan sorotan yang tajam oleh aparat pemerintah. Berbagai peraturan pajak di buat untuk mendukung jumlah penerimaan negara. Untuk mendukung jumlah penerimaan negara ini, wajib pajak diharuskan untuk patuh dalam membayar dan melaporkan pajak. Dengan patuhnya wajib pajak dalam membayar dan melaporkan pajaknya akan meningkatkan penerimaan negara, sehingga negara tidak dirugikan.

Tingkat kepatuhan wajib pajak dipengaruhi oleh dua hal yaitu lingkungan internal dan lingkungan eksternal (Widagsono, 2017). Pengaruh lingkungan internal berasal dari wajib pajak sendiri, sedangkan lingkungan eksternal berasal dari luar wajib pajak itu sendiri. Penelitian ini memfokuskan untuk membahas pengaruh internal di antaranya : religiusitas dan kesadaran wajib pajak. Religiusitas merupakan tingkat keterikatan seseorang terhadap agama yang di anut masing-masing individu (Widagsono, 2017). Semua agama di dunia ini memberikan petunjuk yang baik bagi pemeluk agamanya dengan menganjurkan untuk berperilaku yang baik dan mematuhi norma-norma yang berlaku.

Bagi seseorang yang memiliki pengetahuan agama yang banyak, keyakinan terhadap agamanya, akan 
menciptakan seseorang yang bereligius. Jadi tingkat religiusitas seseorang ini berusaha berperilaku sesuai dengan kaidah norma yang berlaku. Begitu juga ketika wajib pajak yang memiliki religiusitas yang tinggi akan berusaha untuk patuh terhadap peraturan perpajakan. Menurut Utama dan Wahyudi (2016), Benk, et al (2016), Retyowati (2016), Anggraeni (2016) religiusitas berpengaruh terhadap kepatuhan wajib pajak. Berbeda dengan penelitian yang telah dilakukan oleh Widagsono (2017), Wati (2016), Rahmawaty (2014) menunjukkan bahwa religiusitas tidak berpengaruh terhadap kepatuhan wajib pajak. Hal ini dikarenakan wajib pajak memiliki pandangan yang berbeda antara urusan agama dengan urusan bisnis.

Kepatuhan wajib pajak di Indonesia masih rendah, hal ini dikarenakan masyarakat Indonesia belum begitu sadar dengan pentingnya peran pajak bagi kesejahteraan rakyat Indonesia. Wajib pajak di Indonesia beranggapan bahwa peraturan pajak makin lama makin memberatkan wajib pajak sehingga wajib pajak enggan untuk membayar pajak. Selain itu rendahnya tingkat kepatuhan wajib pajak di Indonesia dikarenakan wajib pajak hanya sekedar memenuhi kewajiban pajak untuk menghindari adanya pemeriksaan pajak dan menghindari denda pajak (Mayasari, et al, 2014). Sejalan dengan penelitian yang telah dilakukan oleh Anggraeni (2016) menunjukkan bahwa semakin tinggi tingkat kesadaran yang dimiliki oleh wajib pajak maka semakin tinggi pula tingkat kepatuhan yang dimiliki oleh wajib pajak. Tetapi berbeda dengan penelitian yang telah dilakukan oleh Tahar dan Rachman (2014), yang menunjukkan bahwa kesadaran wajib pajak tidak dapat berpengaruh terhadap kepatuhan wajib pajak karena wajib pajak membayar pajak hanya karena takut untuk mendapatkan sanksi denda bukan karena dari kesadaran wajib pajak.

Penelitian ini mengacu pada penelitian yang telah dilakukan oleh Utama (2016) dengan menambah variabel intervening kesadaran wajib pajak. Berdasarkan riset gap di atas maka penelitian ini berjudul “Pengaruh Religiusitas Terhadap Kepatuhan Wajib Pajak dengan kesadaran wajib pajak Sebagai Variabel Intervening (Studi Kasus pada Wajib Pajak Orang Pribadi yang Terdaftar pada Kantor Pelayanan Pajak (KPP) Pratama Kudus)".

\section{Perumusan Masalah}

Berdasarkan uraian pada latar belakang yang telah dijelaskan di atas, maka permasalahan tersebut dirumuskan dalam pertanyaan penelitian sebagai berikut : 1). Apakah religiusitas berpengaruh terhadap kepatuhan wajib pajak? 2). Apakah religiusitas berpengaruh terhadap kesadaran wajib pajak? 3). Apakah kesadaran wajib pajak berpengaruh terhadap kepatuhan wajib pajak? 4). Apakah kesadaran wajib pajak memediasi hubungan antara religiusitas terhadap kepatuhan wajib pajak?

\section{KAJIAN PUSTAKA DAN PENGEMBANGAN HIPOTESIS}

\section{Theory of Planned Behavior (TPB)}

Theory of Planned Behaviour merupakan teori tentang perilaku seseorang. Perilaku seseorang untuk termotivasi melakukan sesuatu. Disini motivasi yang dimiliki oleh wajib pajak dalam memenuhi kewajibannya dalam hal perpajakan. Menurut Tyas (2013), Bobek \& Hatfield (2003), Hanno dan Violette (1996), teori ini digunakan untk mengetahui seberapa jauh tingkat kepatuhan wajib pajak atas peraturan pajak. Theory of Planned Behaviour merupakan alat kontrol yang digunakan untuk memprediksi perilaku wajib pajak. Teori ini 
menunjukkan seberapa besar usaha wajib pajak dalam mematuhi peraturan perpajakan, misalnya : kepatuhan wajib pajak dalam membayar pajak secara tepat waktu, kepatuhan wajib pajak dalam melaporkan Surat Pemberitahuan (SPT) baik masa maupun tahunan.

Menurut Ajzen (2005) Theory of Planned Behaviour merupakan minat yang dimiliki seseorang dalam berperilaku. Dalam hal ini, wajib pajak yang patuh terhadap peraturan perpajakan ini disebabkan karena persepsi wajib pajak bahwa wajib pajak itu harus sadar bahwa peran dari pajak sangat mendukung perekonomian. Selain kesadaran wajib pajak persepsi individu terhadap kontrol ini dapat dilihat seberapa besar tingkat religiusitas yang dimiliki oleh wajib pajak.

\section{Religiusitas dan Kepatuhan Wajib Pajak}

Religiusitas merupakan sikap keagamaan seseorang untuk berlaku jujur dan bertindak adil sesuai dengan kepercayaan masing-masing. Religiusitas yang dimiliki oleh seseorang ini akan berdampak bagus terhadap perilaku seseorang. Seseorang yang memiliki sikap jujur dalam kehidupan sehari-harinya akan bertindak bijaksana. Tindakan bijaksana ini dapat dilihat dari sikap seseorang dalam menjalankan kewajiban yang harus dilakukan. Salah satu kewajiban dari wajib pajak adalah kewajiban untuk memenuhi kewajiban perpajakan yaitu kewajiban membayar pajak dan kewajiban melaporkan pajak. Wajib pajak yang memenuhi kewajiban pajak ini disebut dengan kepatuhan wajib pajak. Dengan kata lain, wajib pajak yang memiliki tingkat religiusitas yang tinggi akan meningkatkan kepatuhan wajib pajak dalam memenuhi kewajiban pajak. Wajib pajak yang religius berusaha untuk mematuhi norma dan aturan yang berlaku (Mayasari, et al, 2014).

Wajib pajak yang mematuhi peraturan pajak ini akan termotivasi untuk membayar pajak dan melaporkan pajak tepat waktu. Wajib pajak yang religius akan berusaha mematuhi kewajiban yang semestinya harus dikerjakan. Kewajiban pajak ini akan ditepati karena ajaran agama memberikan ajaran untuk berperilaku jujur. Artinya semakin tinggi tingkat religius yang dimiliki oleh wajib pajak akan meningkatkan kepatuhan pajak dalam memenuhi kewajiban pajaknya. Bukti penelitian yang menghasilkan religiusitas berpengaruh terhadap kepatuhan wajib pajak ini diantaranya : Torgler (2012), Mckerchar, et al (2013), Raihana dan Ali (2013), Utama dan Wahyudi (2016), Benk, et al (2016), Retyowati (2016), Anggraeni (2016). Berdasarkan keterangan diatas, maka hipotesis yang diajukan dalam penelitian ini sebagai berikut :

\section{H1 : Religiusitas berpengaruh positif terhadap kepatuhan wajib pajak}

\section{Religiusitas dan Kesadaran Wajib Pajak}

Religiusitas memungkinkan seseorang untuk mematuhi aturan-aturan yang berlaku. Hal ini disebabkan karena seseorang yang memiliki religiusitas tinggi berusaha untuk tidak melanggar aturan yang berlaku. Wajib pajak yang memiliki religiusitas yang tinggi akan membatasi dirinya untuk tidak menggelapkan pajak (Cahyonowati, 2011). Bagi wajib pajak yang memiliki religiusitas yang tinggi, mereka akan lebih banyak memperdalam agama sehingga membentuk tingkat kejujuran yang tinggi. Dengan tingkat kejujuran yang tinggi ini memungkinkan wajib pajak untuk sadar atas kewajiban yang harus di tunaikan. Selanjutnya wajib pajak akan merasa tergerak hatinya untuk membayar pajak tepat waktu. Begitu juga wajib pajak akan melaporkan pajak tepat waktu. Menurut Widagsono (2017) seseorang yang memiliki religiusitas yang tinggi akan berusaha 
menerapkan nilai-nilai agama yang dipraktekkan dalam kehidupan sehari-hari. Penerapan nilai-nilai agama ini ditunjukkan dengan tingginya kesadaran yang dimiliki oleh wajib pajak dalam memenuhi kewajiban pajaknya. Karena wajib pajak yang religius ini menganggap bahwa kewajiban pajak itu harus dipenuhi, sehingga wajib pajak secara sadar dan sukarela untuk memenuhi kewajiban perpajakan. Berdasarkan keterangan di atas, maka hipotesis penelitian yang di ajukan sebagai berikut:

\section{H2 : Religiusitas berpengaruh positif terhadap kesadaran wajib pajak}

\section{Kesadaran Wajib Pajak dan Kepatuhan Wajib Pajak}

Sistem pemungutan pajak di Indonesia menggunakan metode Self Assesmet System, dimana wajib pajak diberi kebebasan untuk menghitung, membayar dan melaporkan pajaknya. Kebebasan ini memberikan dampak bagi wajib pajak untuk lebih fleksibel dalam menentukan jumlah pajak yang dibayar. Hal ini dapat menumbuhkan tingkat kesadaran wajib pajak karena wajib pajak merasa diberikan keringanan untuk menghitung pajaknya sendiri. Wajib pajak akan bersedia untuk membayar pajak karena kebebasan yang diberikan oleh pihak aparat pajak. Selanjutnya dengan kesediaan dan kesadaran yang dimiliki wajib pajak dalam membayar pajak ini akan meningkatkan kepatuhan wajib pajak secara jujur dan akurat (Pasaribu dan Christine (2016). Selain itu wajib pajak menganggap bahwa pajak merupakan kewajiban bagi wajib pajak (Anggraeni, 2016). Dimana wajib pajak sadar bahwa pajak dapat mendukung jalannya perekonomian negara sehingga wajib pajak akan bersedia membayar pajak secara tepat waktu.

Penelitian terdahulu yang menghasilkan kesadaran wajib pajak berpengaruh terhadap kepatuhan wajib pajak di antaranya : Utami, et al (2011), Arum (2012), Jotopurnomo, et al (2013), Sumantri dan Astrini (2013), Khasanah (2014), Anggraeni (2016), Effendi dan Aris (2016). Berdasarkan keterangan di atas maka, hipotesis yang diajukan dalam penelitian ini sebagai berikut :

\section{H3 : Kesadaran wajib pajak berpengaruh positif terhadap kepatuhan wajib pajak}

\section{Religiusitas, Kesadaran Wajib Pajak dan Kepatuhan Wajib Pajak}

Tingkat religiusitas wajib pajak ditunjukkan dengan sikap jujur wajib pajak dalam memenuhi kewajiban pajaknya. Wajib pajak yang memiliki tingkat kejujuran yang tinggi akan memiliki pemikiran yang bijaksana dalam hal perpajakan. Bagi wajib pajak yang memiliki religiusitas yang tinggi ini akan berusaha mematuhi peraturan perpajakan. Hal ini dikarenakan wajib pajak menganggap bahwa membayar pajak adalah sebuah kewajiban. Bagi wajib pajak yang religius memandang kewajiban adalah hal yang harus di taati. Pemikiran tersebut merupakan suatu kesadaran yang dimiliki oleh wajib pajak. Selanjutnya wajib pajak yang sadar bahwa pajak adalah sebuah kewajiban, maka wajib pajak akan berusaha patuh dengan peraturan perpajakan (Torgler, 2012).

Wajib pajak akan dengan sukarela mematuhi peraturan perpajakan walaupun menurut wajib pajak ini tidak adil karena mereka membayar iuran pajak tanpa mendapatkan timbal balik secara langsung (Pope dan Mohdali, 2010). Hal ini menunjukkan tingkat kesadaran yang tinggi dari wajib pajak akan meningkatkan kepatuhan wajib pajak. Menurut Pope dan Mohdali (2010) religiusitas ini akan berdampak baik terhadap moral wajib pajak, dimana moral pajak disini berupa kesadaran wajib pajak dalam memenuhi kewajiban pajak. 
Selanjutnya wajib pajak yang memiliki kesadaran tinggi akan termotivasi untuk membayar pajak (Togler, 2012). Wajib pajak yang sadar akan pentingnya membayar pajak akan termotivasi untuk membayar pajak secara tepat waktu, karena hampir $80 \%$ anggaran pendapatan dan belanja negara bersumber dari pajak. Berdasarkan keterangan di atas maka hipotesis penelitian yang dapat diajukan sebagai berikut:

H4 : Kesadaran wajib pajak memediasi hubungan antara religiusitas terhadap kepatuhan wajib pajak

Kerangka penelitian yang mewakili dari beberapa hipotesis di atas dapat dilihat pada lampiran gambar 1.

\section{Populasi dan Sampel}

\section{METODE PENELITIAN}

Populasi yang digunakan dalam penelitian ini adalah wajib pajak orang pribadi yang ada di KPP Pratama Kudus. Teknik pengambilan sampel yang digunakan adalah teknik insidental sampling yaitu teknik pengambilan sampel dengan cara memberikan kuesioner kepada objek yang ditemui pada saat itu. Hal ini dikarenakan untuk mempermudah dalam mendapatkan sampel. Untuk menentukan jumlah sampel yang digunakan dalam penelitian menggunakan teori dari Kuncoro dan Sudarman (2018), dimana sampel untuk penelitian multivariate dapat ditentukan jumlahnya sebesar 100 responden.

\section{Definisi Operasional Variabel Penelitian}

Variabel yang digunakan dalam penelitian ini terdiri dari variabel dependen yaitu kepatuhan wajib pajak, variabel independen yaitu religiusitas dan variabel intervening yaitu kesadaran wajib pajak. Kepatuhan wajib pajak (tax compliance) menurut Simon James, et al dalam Santoso (2008) adalah kesediaan wajib pajak untuk memenuhi kewajiban pajaknya sesuai dengan aturan yang berlaku tanpa perlu diadakannya pemeriksaan, investigasi seksama, peringatan, ataupun ancaman dan penerapan sanksi baik hukum maupun administratif. Pope dan Mohdali (2010) religiusitas adalah keyakinan moral pribadi yang berasal dari motivasi agama. Religiusitas menggunakan kuisioner yang diadopsi langsung dari Capanna et. al (2013). Kesadaran wajib pajak merupakan suatu kondisi dimana wajib pajak mengetahui, memahami, dan melaksanakan ketentuan perpajakan dengan benar dan sukarela (Anggraeni, 2016). Pengukuran variabel kepatuhan wajib pajak, religiusitas dan kesadaran wajib pajak menggunakan skala ordinal dengan teknik pengukuran 5 (lima) skala Likert.

\section{Teknik Analisis Data}

Analisis data dalam penelitian ini menggunakan pendekatan Structural Equation Model (SEM) dengan menggunakan metode alternatif Partial Least Square (PLS). Software yang digunakan adalah Software Warp PLS 3.0. PLS merupakan model persamaan struktural (SEM) yang berbasis komponen atau (variance). PLS merupakan pendekatan alternatif yang bergeser dari pendekatan SEM yang berbasis covariance menjadi berbasis varian (Ghozali dan Latan, 2012).

Evalusi model pengukuran atau outer model dilakukan untuk menilai validitas dan reliabilitas model (Ghozali dan Latan, 2012). Dalam penelitian ini tidak menggunakan outer model, hal tersebut dikarenakan setiap variabel hanya menggunakan satu indikator pengukur. Evaluasi model struktural atau inner model 
bertujuan untuk memprediksi hubungan antara variabel dependen dengan variabel independen (Ghozali dan Latan, 2012).

Dalam menilai model dengan PLS dimulai dengan melihat $R$-square untuk setiap variabel laten dependen. Interpretasinya sama dengan interpretasi pada regresi. Perubahan nilai $R$-square dapat digunakan untuk menilai pengaruh variabel laten independen tertentu terhadap variabel laten dependen apakah mempunyai pengaruh yang substantif (Ghozali, 2014). 3). Persyaratan efek mediasi yang harus dipenuhi adalah: (i) koefisien jalur c signifkan pada model (1), dan (ii) koefisien jalur a dan b harus signifikan pada model (2). Pengambilan kesimpulan tentang mediasi adalah sebagai berikut (Sholihin dan Ratmono, 2013) : 1). Jika koefisien jalur c" dari hasil estimasi model (2) tetap signifikan dan tidak berubah $\left(c^{\prime \prime}=c\right)$ maka hipotesis mediasi tidak didukung. 2). Jika koefisien jalur $c^{\prime \prime}$ nilainya turun $\left(c^{\prime \prime}<c\right)$ tetapi tetap signifikan maka bentuk mediasi adalah mediasi sebagian (partial mediation). 3). Jika koefisien jalur $c^{\prime \prime}$ nilainya turun $\left(c^{\prime \prime}<c\right)$ dan menjadi tidak signifikan maka bentuk mediasi adalah mediasi penuh (full mediation).

\section{Penyajian Data \\ Hasil Uji Instrumen}

HASIL DAN PEMBAHASAN

Sesuai dengan prosedur pengujian SEM-PLS, maka evaluasi validitas konvergen konstruk menggunakan indikator berupa loading factor dan average variance extracted (AVE). Hasil outer model dengan program warp PLS pada tabel 1 menunjukkan kriteria validitas konvergen telah terpenuhi yaitu loading lebih besar dari 0,60 dan AVE lebih besar dari 0,40. Selanjutnya untuk menunjukkan kriteria validitas diskriminan telah terpenuhi ditunjukkan dengan akar kuadrat AVE lebih besar daripada koefisien korelasi antar konstruk pada masingmasing kolom. Demikian juga reliabilitas telah terpenuhi dengan composite reliability dan cronbach alpha lebih besar dari 0,60.

\section{Hasil Korelasi antar Konstruk}

Matriks korelasi pada tabel 2 menunjukkan terdapat hubungan positif yang cukup kuat antara RLGS $\rightarrow$ KWP, ditunjukkan dengan koefisien korelasi signifikan. Terdapat hubungan positif antara RLGS $\rightarrow$ KSWP, dengan koefisien korelasi signifikan. Terdapat hubungan positif antara KWP $\rightarrow$ KSWP dengan koefisien korelasi signifikan. Hasil ini menunjukkan indikasi awal dukungan terhadap hipotesis mediasi karena hubungan mediasi mensyaratkan korelasi signifikan antara variabel independen, pemediasi, dan dependen.

\section{Hasil Pengujian Model Mediasi}

Hasil pengujian model mediasi disajikan pada tabel 3. Hasil estimasi model (1) dan (2) menunjukkan kriteria goodness of fit telah terpenuhi yaitu nilai APC dan ARS signifikan secara statistis dan AVIF kurang dari 5. Hasil pada Tabel 3 menunjukkan bahwa persyaratan untuk pengujian mediasi telah terpenuhi yaitu koefisien c, a, dan b.

Prosedur pengujian KSWP sebagai variabel pemediasi hubungan antara RLGS terhadap KWP adalah sebagai berikut : 1).Melakukan estimasi direct effect RLGS terhadap KWP (jalur c) yang terlampir pada gambar 2. 2). Melakukan estimasi indirect effect secara simultan dengan triangle PLS SEM Model yaitu RLGS $\rightarrow$ KWP (Jalur 
$\left.c^{\prime \prime}\right)$, RLGS $\rightarrow$ KSWP (jalur a), dan KWP $\rightarrow$ KSWP (Jalur b) yang terlampir pada gambar 3. Berdasarkan gambar 2 dan gambar 3 di dapatkan nilai $c^{\prime \prime}<$ c. Ringkasan pengujian secara langsung dan tidak langsung dapat dilihat pada tabel 4. Berdasarkan table 4 menunjukkan bahwa kesadaran wajib pajak merupakan mediasi sebagian pengaruh antara religiusitas terhadap kepatuhan wajib pajak.

\section{PEMBAHASAN}

Ringkasan hasil pengujian hipotesis terlampir pada tabel 5.

\section{Religiusitas Berpengaruh Terhadap Kepatuhan Wajib Pajak}

Hipotesis pertama yang diajukan dalam penelitian yaitu religiusitas berpengaruh terhadap kepatuhan wajib pajak. Hasil pengujian statistik dapat disimpulkan bahwa religiusitas berpengaruh terhadap kepatuhan wajib pajak orang pribadi yang terdaftar pada Kantor Pelayanan Pajak (KPP) Pratama Kudus. Hal ini sejalan dengan teori tentang keperilakuan yaitu Theory of Planned Behaviour. Teori ini menjelaskan tentang bagaimana seseorang mampu berperilaku, ketika seseorang tersebut memiliki niat dan motivasi. Bagi wajib pajak yang memiliki religiusitas yang tinggi, berarti wajib pajak mampu membedakan mana perilaku yang baik dan mana perilaku yang buruk. Dalam hal perpajakan, wajib pajak yang baik seharusnya mematuhi segala yang terkait dengan peraturan perpajakan. Wajib pajak beranggapan bahwa dengan mematuhi segala peraturan perpajakan sama halnya dengan mematuhi ajaran agama. Karena semua agama di dunia selalu mengajarkan tentang kebaikan. Wajib pajak yang paham betul tentang agama akan berlaku mematuhi peraturan perpajakan. Dengan wajib pajak membayar pajak berarti, wajib pajak berperilaku yang baik. Dengan berperilaku yang baik berarti wajib pajak mematuhi segala peraturan perpajakan.

Hasil penelitian ini mendukung penelitian yang pernah dilakukan oleh : Benk, et al (2016), Retyowati (2016), Anggraeni (2016), Ermawati (2018). Namun penelitian ini tidak mendukung penelitian yang telah dilakukan oleh Widagsono (2017), Wati (2016), Rahmawaty (2014).

\section{Religiusitas Berpengaruh Terhadap Kesadaran Wajib Pajak}

Hipotesis yang kedua disimpulkan bahwa religiusitas berpengaruh terhadap kesadaran wajib pajak. Hal ini sejalan dengan Theory of Planned Behaviour, yaitu teori yang memotivasi wajib pajak dalam menunaikan kewajiban perpajakannya. Selanjutnya tingkat religiusitas wajib pajak merupakan tingkatan wajib pajak tentang seberapa jauh wajib pajak mempercayai dan meyakini agama masing-masing sehingga menjalankan ajaran agama nya masing-masing. Tiap - tiap agama pasti mengajarkan suatu kebaikan. Hal ini dapat dilihat dari sikap wajib pajak dalam menyelesaikan kewajiban perpajakannya. Wajib pajak yang memiliki religiusitas yang tinggi berarti wajib pajak akan menjalankan kewajiban perpajakan. Hal ini dikarenakan wajib pajak yang paham betul tentang agama akan berbuat kebaikan. Hal ini lah yang mendorong wajib pajak memiliki kesadaran yang tinggi tentang arti penting dari peran pajak bagi Negara. Wajib pajak yang taat pada agama akan menyadari betapa pentingnya pajak untuk pembangunan Negara. Disini wajib pajak secara sadar dan tanpa paksaan untuk mematuhi segala kewajiban perpajakan.

Hasil penelitian ini sejalan dengan penelitian yang telah dilakukan oleh Cahyonowati (2011) dan Widagsono (2017), yang menyimpulkan bahwa wajib pajak yang memiliki religiusitas yang tinggi tidak akan 
berbuat kejahatan dengan cara menggelapkan pajak karena wajib pajak sadar bahwa dengan menggelapkan pajak berarti melakukan suatu kejahatan yang dilarang oleh agama.

\section{Kesadaran Wajib Pajak Berpengaruh Terhadap Kepatuhan Wajib Pajak}

Hipotesis yang ketiga dapat disimpulkan bahwa kesadaran wajib pajak berpengaruh terhadap kepatuhan wajib pajak. Hasil penelitian ini sejalan dengan Theory of Planned Behaviour, dimana wajib pajak yang telah menyadari betapa pentingnya pajak bagi Negara akan termotivasi untuk membayar pajak sesuai dengan aturan perpajakan. Motivasi dan niat yang dimiliki oleh wajib pajak ini, berasal dari hati nurani wajib pajak itu sendiri. Bagi wajib pajak yang menyadari bahwa fungsi dari membayar pajak itu sendiri dapat mendukung Anggaran Pendapatan Dan Belanja Negara maka wajib pajak akan membayar pajak tepat waktu. Selain itu menurut Pasaribu dan Christine (2016), kesadaran wajib pajak ini tumbuh karena sistem pemungutan pajak yang menganut Self Assesmet System. Sistem ini yang memberikan kebebasan bagi wajib pajak dalam menghitung, membayar dan melaporkan pajak. Kebebasan yang diberikan oleh pemerintah kepada wajib pajak ini akan berdampak baik. Karena wajib pajak menganggap dalam memenuhi kewajiban perpajakan tidak ada intervensi dari pemerintah berapa jumlah pajak yang seharusnya dibayar. Hal inilah yang menumbuhkan kesadaran bagi wajib pajak. kesadaran yang tinggi wajib pajak dalam memenuhi kewajiban perpajakan ini akan berdampak terhadap pemenuhan kewajiban perpajakan yang sesuai dengan peraturan perpajakan. Dengan kata lain, wajib pajak yang sadar bahwa pajak itu suatu kewajiban maka wajib pajak akan segera membayar pajak tepat waktu.

Hasil penelitian ini sejalan dengan penelitian yang telah dilakukan oleh Khasanah (2014), Anggraeni (2016), Effendi dan Aris (2016), Ermawati (2018). Namun penelitian ini tidak sejalan dengan penelitian yang telah dilakukan oleh Nugroho, et al (2016).

\section{Kesadaran Wajib Pajak Memediasi Hubungan Antara Religiusitas Terhadap Kepatuhan Wajib Pajak}

Berdasarkan pengujian statistik di atas dapat disimpulkan bahwa kesadaran wajib pajak memediasi hubungan antara religiusitas terhadap kepatuhan wajib pajak. Tingkat religiusitas yang dimiliki oleh wajib pajak orang pribadi di Kabupaten Kudus ini tergolong tinggi. Hal ini menunjukkan tingkat pemahaman tentang agama bagi wajib pajak orang pribadi ini tinggi. Bagi wajib pajak yang paham tentang agama masing-masing yang di anut maka wajib pajak tersebut dalam kehidupan sehari-harinya memiliki komitmen dalam diri wajib pajak. Wajib pajak yang religius ini berkomitmen untuk mematuhi segala ajaran agama. Wajib pajak yang patuh terhadap ajaran agama, akan berusaha berbuat kebaikan. Perbuatan kebaikan selanjutnya adalah wajib pajak memiliki kesadaran diri untuk membayar pajak. Dengan wajib pajak membayar pajak tanpa adanya paksaan, maka wajib pajak dapat mendukung perekonomian Negara. Wajib pajak yang memiliki religiusitas tinggi akan memiliki kesadaran yang tinggi juga dalam memahami peran pajak bagi masyarakat. Sehingga wajib pajak yang religius tidak akan merasa terpaksa ketika membayar pajak.

Sesuaidengan sistem pemungutan pajakdi Indonesiayang menganut SelfAssesmet System, menumbuhkan kesadaran bagi wajib pajak dalam membayar pajak. Sistem tersebut memberikan suatu kebebasan bagi wajib 
pajak untuk dapat menghitung sendiri jumlah pajak yang seharusnya dibayar. Dengan kebebasan tersebut otomatis tingkat kesadaran yang dimiliki oleh wajib tinggi. Selanjutnya sesuai dengan Theory of Planned Behavior, wajib pajak yang memiliki kesadaran yang tinggi tentang peran penting pajak bagi pemerintah, maka wajib pajak akan termotivasi untuk membayar pajak dan melaporkan pajak tepat waktu. Hal ini menunjukkan bahwa wajib pajak yang memliki religiusitas yang tinggi akan menumbuhkan kesadaran yang tinggi bagi wajib pajak mengenai membayar pajak merupakan suatu kewajiban. Dengan tingkat kesadaran wajib pajak yang tinggi mendorong wajib pajak untuk mematuhi segala yang terkait dengan peraturan perpajakan.

Sistem pemungutan pajak di Indonesia menggunakan metode Self Assesmet System, dimana wajib pajak diberi kebebasan untuk menghitung, membayar dan melaporkan pajaknya. Kebebasan ini memberikan dampak bagi wajib pajak untuk lebih fleksibel dalam menentukan jumlah pajak yang dibayar. Hal ini dapat menumbuhkan tingkat kesadaran wajib pajak karena wajib pajak merasa diberikan keringanan untuk menghitung pajaknya sendiri. Wajib pajak akan bersedia untuk membayar pajak karena kebebasan yang diberikan oleh pihak aparat pajak. Selanjutnya dengan kesediaan dan kesadaran yang dimiliki wajib pajak dalam membayar pajak ini akan meningkatkan kepatuhan wajib pajak secara jujur dan akurat (Pasaribu dan Christine (2016). Selain itu wajib pajak menganggap bahwa pajak merupakan kewajiban bagi wajib pajak (Anggraeni, 2016). Dimana wajib pajak sadar bahwa pajak dapat mendukung jalannya perekonomian negara sehingga wajib pajak akan bersedia membayar pajak secara tepat waktu.

Hasil penelitian ini mendukung penelitian yang telah dilakukan oleh Anggraeni (2016), Effendi dan Aris (2016) menunjukkan bahwa semakin tinggi tingkat kesadaran yang dimiliki oleh wajib pajak maka semakin tinggi pula tingkat kepatuhan yang dimiliki oleh wajib pajak. Hasil yang berbeda ditemukan oleh Ermawati dan Afifi (2018) yang menunjukkan bahwa kesadaran wajib pajak tidak dapat berpengaruh terhadap kepatuhan wajib pajak karena wajib pajak membayar pajak hanya karena takut untuk mendapatkan sanksi denda bukan karena dari kesadaran wajib pajak.

\section{KESIMPULAN}

Kesimpulan dari hasil penelitian di atas dapat diringkas sebagai berikut : 1). Religiusitas berpengaruh terhadap kepatuhan wajib pajak. 2). Religiusitas berpengaruh terhadap kesadaran wajib pajak. 3). Kesadaran wajib pajak berpengaruh terhadap kepatuhan wajib pajak. 4). Kesadaran wajib pajak mampu memediasi sebagian pengaruh religiusitas terhadap kepatuhan wajib pajak.

\section{Saran}

Saran yang dapat penulis berikan untuk penelitian selanjutnya sebagai berikut : 1). Menambah variabel intervening misalnya : pengetahuan perpajakan, sanksi perpajakan. 2). Teknik pengambilan sampling menggunakan purposive sampling sesuai dengan kriteria yang ditetapkan. 3). Mengubah metode penelitian dengan menggunakan alat analisis jalur path untuk bisa diperbandingkan.

\section{Ucapan Terima Kasih}

Penulis mengucapkan terima kasih kepada Kemenristek Dikti yang telah memberi"dukungan financial" 
terhadap penelitian ini. Penelitian ini merupakan hasil luaran tambahan dari penelitian dengan skema Penelitian Dosen Pemula untuk Tahun Anggaran Tahun 2018.

\section{DAFTAR PUSTAKA}

Ajzen, I. 2005. Attitudes, Personality and Behavior. New York. USA: Open University Press.

Ancok, D. Suroso, F. 2011. Psikologi Islami : Solusi Islam Atas Problem-Problem Psikologi. Yogyakarta : Pustaka Pelajar.

Anggraeni Lady Ayu. 2016. Pengaruh Kesadaran Wajib Pajak, Lingkungan Wajib Pajak, Sikap Religiusitas Wajib Pajak, Dan Kemanfaatan Npwp Terhadap Kepatuhan Wajib Pajak (Studi Empiris pada Wajib Pajak Orang Pribadi yang Terdaftar di Kantor Pelayanan Pajak Pratama Klaten). Skripsi. Fakultas Ekonomi Dan Bisnis, Jurusan Akuntansi Universitas Muhammadiyah Yogyakarta.

Arum Harjanti Puspa. 2012. Pengaruh Kesadaran Wajib Pajak, Pelayanan Fiskus, Dan Sanksi Pajak Terhadap Kepatuhan Wajib Pajak Orang Pribadi Yang Melakukan Kegiatan Usaha Dan Pekerjaan Bebas (Studi Di Wilayah KPP Pratama Cilacap). Skripsi. Program Sarjana Fakultas Ekonomi Universitas Diponegoro.

Benk Serkan, Tamer Budak, Bahadır Yüzba, Raihana Mohdali. 2016. The Impact Of Religiosity On Tax Compliance Among Turkish Self-Employed Taxpayers. Religions 2016, 7, 37; Doi:10.3390/Rel7040037.

Bobek, Richard C, Hatfield. 2003. An Investigation of Theory of Planned Behavior and The Role of Moral Obligation on Tax Compliance. Behavioral Research in Accounting Vol. 15.

Brotodihardjo, Santoso, 2008, Pengantar Ilmu Hukum Pajak, PT. Refika Aditama, Bandung.

Cahyonowati Nur. 2011. Model Moral dan Kepatuhan Perpajakan : Wajib Pajak Orang Pribadi. JAAI Volume 15 No.2 Desember 2011, Hal 161-177

Capanna Cristina, Paolo Stratta, Alberto Collazzoni and Alessandro Rossi. 2013. Construct and Concurrent Validity of the Italian Version of the Brief Multidimensional Measure of Religiousness/Spirituality. Psychology of Religion and Spirituality 2013, Vol. 5, No. 4, 316-324. University of L'Aquila.

Effendi Miftahuddin, Muhammad Abdul Aris. 2016. Analisis Faktor-Faktor Yang Mempengaruhi Kepatuhan Wajib Pajak Dalam Pemenuhan Kewajiban Perpajakannya (Studi Empiris Pada Wajib Pajak Orang Pribadi Yang Terdaftar Di Kantor Pelayanan Pajak Pratama Surakarta). Seminar Nasional Dan Call For Paper Program Studi Akuntansi-Feb Ums, 25 Juni 2014 Isbn: 978-602-70429-2-6 Syariah Accounting Paper FEB-UMS.

Ermawati Nanik. 2018. Pengaruh Religiusitas, Kesadaran Wajib Pajak Dan Pengetahuan Perpajakan Terhadap Kepatuhan Wajib Pajak. Jurnal STIE Semarang Vol 10 No 1 (2018): VOLUME 10 NOMOR 1 EDISI FEBRUARI 2018

Imam Ghozali. 2014. Partial Least Squares Konsep, Metode Dan Aplikasi Menggunakan Porgram Warp PLS 4.0, Badan Penerbit Universitas Diponegoro, Semarang.

Ghozali, Imam. Hengky Latan. 2012. Partial Least Square. "Konsep Teknik dan Aplikasi". Smart PLS2.0M3. Semarang Badan Penerbit : Universitas Diponegoro. 
Hadi, Syamsul, 2006. Metodologi Penelitian Kuantitatif untuk Akuntansi Keuangan, Edisi Pertama, Ekonisia, Yokyakarta.

Hanno, D.M. and G. R.Violette. 1996, An Analysis of Moral and Social Influences on Taxpayer Behaviour. Behaviour Research in Accounting 8 (Supplement).

Jotopurnomo, Cindy dan Yenni Mangoting. 2013. “Pengaruh Kesadaran Wajib Pajak, Kualitas Pelayanan Fiskus, Sanksi Perpajakan, Lingkungan Wajib Pajak Berada Terhadap Kepatuhan Wajib Pajak Orang Pribadi di Surabaya". Tax \& Accounting Review,Vol 1, No 1.

Khasanah Septiyani Nur. 2014.Pengaruh Pengetahuan Perpajakan, Modernisasi Sistem Administrasi Perpajakan, Dan Kesadaran Wajib Pajak Terhadap Kepatuhan Wajib Pajak Pada Kantor Wilayah Direktorat Jenderal Pajak Daerah Istimewa Yogyakarta. Skripsi. Fakultas Ekonomi Universitas Negeri Yogyakarta.

Kuncoro, A, Sudarman. 2018. Metodologi Penelitian Manajemen. Penerbit Andi : Yogyakarta

Mardiasmo. 2016. Perpajakan Edisi Revisi 2013. Yogyakarta. Penerbit Andi.

Mayasari Wana, Zaitul, Resti Yulistia Muslim. 2015. Pengaruh Ketaatan Beragama Terhadap Moral Pajak. Ejurnal Universitas Bung Hatta. Vol 6, No 1.

Mckerchar, M., Bloomquist, K., \& Pope, J. 2013. Indicators Of Tax Morale: An Exploratory Study. Ejournal Of Tax Research, 11(1), 5-22.

Nawangsari, R. 2010. Pengaruh Persepsi Wajib Pajak atas Pelayanan Publik, Iklan Pajak, dan Kesadaran Wajib Pajak terhadap Kepatuhan Wajib Pajak. Skripsi. UMY. Yogyakarta.

Nugroho Aditya, Rita Andini, Kharis Raharjo. 2016. Pengaruh Kesadaran Wajib Pajak Dan Pengetahuan Perpajakan Wajib Pajak Terhadap Kepatuhan Wajib Pajak Dalam Membayar Pajak Penghasilan (Studi Kasus Pada KPP Semarang Candi). Journal Of Accounting, Volume 2 No.2 Maret 2016

Pasaribu Ganda Frisno, Christine Tjen. 2016. Dampak Faktor-Faktor Demografi Terhadap Kepatuhan Perpajakan di Indonesia. Baki (Berkala Akuntansi dan Keuangan Indonesia. Volume 1. No. 2

Pope, J., dan R. Mohdali. 2010. Role of Religiosity in Tax Morale and Tax Compliance, The. Austl. Tax F., 25, 565596

Purwono, Heri. 2010. Dasar-Dasar Perpajakan dan Akuntansi Pajak. Jakarta : Erlangga.

Rahmawaty, Stella. 2014. "Pengaruh Pengetahuan Modernisasi Strategi Direktoral Jenderal Pajak, Sanksi Perpajakan dan Religiusitas yang Dipersepsikan Terhadap Kepatuhan Perpajakan". Jurnal IImiah Mahasiswa Fakultas Ekonomi dan Bisnis Universitas Brawijaya, Vol 3, No 1.

Rahman, I. S. 2013. Pengaruh Faktor-Faktor Eksternal terhadap tingkat Kepatuhan Membayar Pajak: Studi Empiris terhadap Wajib Pajak Orang Pribadi di Kantor Pelayanan Pajak Pratama Indramayu. Skripsi. UMY. Yogyakarta.

Raihana Nor, Mohd Ali. 2013. The Influence Of Religiosity On Tax Compliance In Malaysia. Thesis The Degree Of Doctor Of Philosophy Of Curtin University.

Resmi, Siti. 2013. Perpajakan. Jakarta: Salemba Empat.

Retyowati Fitriana Dikky. 2016. Analisis Faktor-Faktor Yang Mempengaruhi Ketidakpatuhan Wajib Pajak 
Yang Terdaftar Pada KPP Pratama Sukoharjo. Publikasi Ilmiah Fakultas Ekonomi Dan Bisnis Universitas Muhammadiyah Surakarta.

Setyonugroho, H. 2012. Faktor-Faktor yang Memengaruhi untuk Membayar Pajak pada Wajib Pajak Orang Pribadi di KPP Pratama Surabaya Tegalsari, Artikel IImiah, STIE PERBANAS, Surabaya.

Sholihin, Mahfud dan Ratmono, Dwi. (2013). Analisis SEM-PLS dengan WrapPLS 3.0 Untuk Hubungan Nonlinear dalam Penelitian Sosial dan Bisnis. Yogyakarta: Penerbit ANDI.

Sumantri, Putri Astrini. 2013. "Analisis Pengaruh Kesadaran Perpajakan, Lingkungan, dan Sanksi Perpajakan Terhadap Kepatuhan Wajib Pajak. Skripsi, Fakultas Ekonomi, Bandung: Universitas Kristen Maranatha.

Tahar Frizal, Arnain Kartika Rachman. 2014. Pengaruh Faktor Internal Dan Faktor Eksternal Terhadap Kepatuhan Wajib Pajak. Jurnal Akuntansi \& Investasi Vol. 15 No.1 Januari 2014

Torgler, B. 2012. Attitudes Toward Paying Taxes In The Usa: An Empirical Analysis The Ethics Of Tax Evasion. The Ethics Of Tax Evasion: Perspectives In Theory And Practice (Pp. 269-283). New York:Springer.

Tyas Isthi Wahyuning. 2013. Pengaruh Umur, Pendidikan, Penghasilan Bruto, Dan Moral Terhadap Kepatuhan Pembayaran Pajak (Studi Empiris WPOP Usahawan pada Mall Ciputra). Jurnal TEKUN/Volume IV, No. 02, September 2013: 279-304

Uma Sekaran, 2006, Metodologi Penelitian untuk Bisnis, Edisi 4, Buku 2, Jakarta: Salemba Empat.

Undang-Undang No.28 Tahun 2007 Tentang Tata Cara Perpajakan

Utama Andhika, Dudi Wahyudi. 2016. Pengaruh Religiusitas Terhadap Perilaku Kepatuhan Wajib Pajak Orang

Pribadi Di Provinsi DKI Jakarta. Jurnal Lingkar Widyaiswara Edisi 3 No. 2, Apr - Jun 2016, P.01-13 ISSN : 2355-4118

Utami, Sri Rizki, Andi dan Ayu Noorida Soerono., 2012. Pengaruh FaktorFaktor Eksternal Terhadap Tingkat Kepatuhan Wajib Pajak Di Lingkungan Kantor Pelayanan Pajak Pratama Serang. Jurnal Universitas Sultan Ageng Tirtayasa.

Wati, Reny Eka. 2016. Pengaruh Pengetahuan Modernisasi Strategi Direktorat Jenderal Pajak, Sanksi Perpajakan, Kualitas Pelayanan Fiskus dan Religiusitas yang Dipersepsikan Terhadap Kepatuhan Perpajakan. , Naskah Publikasi, Fakultas Ekonomi dan Bisnis, Surakarta: Universitas Muhammadiyah Surakarta.

Widagsono Seto. 2017. Pengaruh Pengetahuan Perpajakan, Sanksi, dan Religiusitas terhadap Kepatuhan Wajib Pajak (Studi Kasus pada KPP Pratama Kepanjen). Skripsi. Jurusan Akuntansi Fakultas Ekonomi Universitas Islam Negeri Maulana Malik Ibrahim Malang.

Widayati dan Nurlis. 2010. "Faktor-faktor yang Mempengaruhi Kemauan untuk Membayar Pajak WAjib Pajak Orang Pribadi yang Melakukan Pekerjaan Bebas (Studi Kasus pada KPP Pratama Gambir Tiga)". Simposium Nasional Akuntansi XIII, Purwokerto. 


\section{LAMPIRAN}

\section{Gambar 1 : Diagram Model Penelitian}

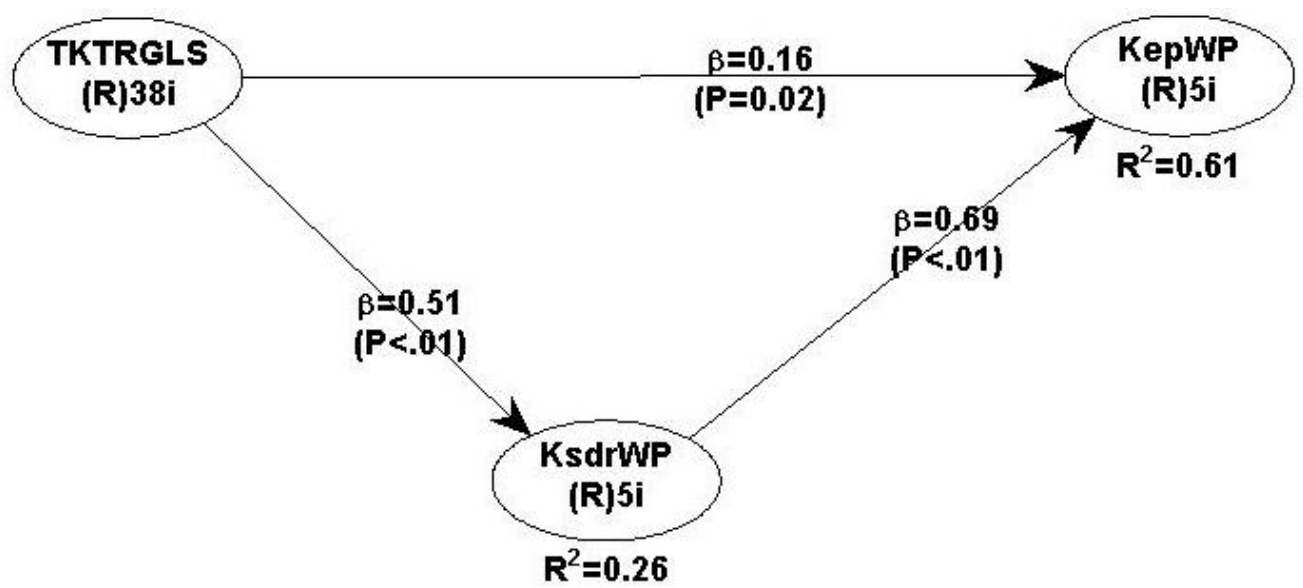

Sumber: Data Primer 2018, yang diolah

Tabel 1

Outer/Measurement Model

\begin{tabular}{|l|c|c|c|c|}
\hline \multicolumn{1}{|c|}{ Konstruk } & Range & AVE & $\begin{array}{c}\text { Composite } \\
\text { Reliability }\end{array}$ & $\begin{array}{c}\text { Cronbach } \\
\text { alpha }\end{array}$ \\
\hline 1. Religiusitas & $0,335-0,786$ & 0,309 & 0,830 & 0,177 \\
\hline 2. Kesadaran Wajib Pajak & $0,503-0,848$ & 0,569 & 0,868 & 0,866 \\
\hline 3. Kepatuhan wajib pajak & $0,451-0,868$ & 0,565 & 0,866 & 0,805 \\
\hline
\end{tabular}

Sumber: Data primer 2018, yang diolah

Tabel 2

Correlations Among Latent Variables

\begin{tabular}{|cccc|}
\hline Component & RLGS & KWP & KSWP \\
RLGS & 0,565 & 0,395 & 0,403 \\
KSWP & 0,555 & 0,395 & 0,754 \\
KWP & 0,395 & 0,752 & 0,763 \\
\hline
\end{tabular}

Sumber: Data Primer 2018, yang diolah

Tabel 3

Goodness Of Fit

\begin{tabular}{|c|cc|c|c|c|}
\hline \multirow{2}{*}{ No } & \multirow{2}{*}{ Jalur } & \multicolumn{2}{c}{ Direct effect } & \multicolumn{2}{c|}{ Indirect effect } \\
& & Koefesien & P-value & Koefesien & P-value \\
1 & APC & 0,500 & $<, 001$ & 0,451 & $<, 001$ \\
\hline 2 & ARS & 0,250 & $<, 001$ & 0,432 & $<, 001$ \\
\hline 3 & AVIF & 1,185 & $<5$ & 1,327 & $<5$ \\
\hline
\end{tabular}

Sumber: Data primer 2018, yang diolah 
Tabel .4

Direct Dan Indirect Effect

\begin{tabular}{|c|cc|c|c|c|}
\hline \multirow{2}{*}{ No } & \multirow{2}{*}{ Jalur } & \multicolumn{2}{c}{ Direct effect } & \multicolumn{2}{c|}{ Indirect effect } \\
& & Koefesien & P-value & Koefesien & P-value \\
1 & RLGS $\rightarrow$ KWP & 0,500 & $<, 01$ & 0,349 & $<, 01$ \\
\hline 2 & RLGS $\rightarrow$ KSWP & 0,076 & $<, 01$ & 0,180 & $<, 01$ \\
\hline 3 & KSWP $\rightarrow$ KWP & 0,250 & $<, 01$ & 0,529 & $<, 01$ \\
\hline
\end{tabular}

Sumber: Data primer 2018, yang diolah

Tabel 5

Ringkasan Hasil Uji Hipotesis

\begin{tabular}{|c|l|c|}
\hline H & \multicolumn{1}{|c|}{ Hipotesis } & Keterangan \\
\hline H1 & Religiusitas berpengaruh terhadap kepatuhan wajib pajak & diterima \\
\hline H2 & Religiusitas berpengaruh terhadap kesadaran wajib pajak & diterima \\
\hline H3 & Kesadaran wajib pajak berpengaruh terhadap kepatuhan wajib pajak & diterima \\
\hline H4 & $\begin{array}{l}\text { Kesadaran wajib pajak memediasi hubungan antara religiusitas terhadap kepatuhan wajib } \\
\text { pajak }\end{array}$ & diterima \\
\hline
\end{tabular}

Sumber: Data primer 2018, yang diolah 